\title{
Analisa Pegaruh Perlindungan Kesehatan dan Keselamatan Kerja Terhadap Peningkatan ProduktivitasKerja Karyawan
}

\author{
Yohanes Parmin
}

\begin{abstract}
Tujuan dari tulisan sederhana ini adalah untuk meninjau betapa pentingnya setiap organisasi melihat dan memperhatikan untuk dicarikan solusinya terhadap rasa keamanan bagi para karyawan yang turut ambil bagian dalam pengembangan orgaisasi. Dalam pendekatan tinjauan, penulis lebih menyoroti terutama dari sudut pengaru antara variabel independen $\left(\mathrm{X}_{1}\right.$ dan $\left.\mathrm{X}_{2}\right)$ terhadap variabel dependen $(\mathrm{Y})$ sekaligus menguji hipotesis yang telah dirumuskan sebelumnya. Populasi dalam dalam tinjauan diambil dari salah satu organisasi yang sedang tumbuh, dengan jumlah sampel sebesar 18 karyawan. Adapaun teknik untuk mengumpulkan data yang digunakan adalah dengan menyebarkan kuesioner dengan menggunakan analisis regresi berganda dengan bantuan program SPSS versi 21. Hasil analisa dalam penelitian sederhana menunjukkan bahwa variabel keselamatan kerja dan kesehatan sebagai variabel independen secara bersama-sama mempunyai pengaruh yang signifikan terhadap kinerja karyawan sebagai variabel dependen, hal ini dapat dilihat dari hasil uji $\mathrm{F}>$ dari $\mathrm{F}$ tabel $(4.259>2.131)$ dengan tingkat signifikansi $\mathrm{F}<\alpha$ yaitu $0,000<0,05$ dan nilai Adjusted $\mathrm{R}$ square sebesar 0,741 atau 74,1\%, hal ini menunjukkan bahwa presentase sumbangan pengaruh variabel independen (kesehatan dan keselamatan kerja) terhadapm variabel dependen (produktivitas kerja) adalah sebesar $74.1 \%$, sementara sisanya sebesar $25.9 \%$ dipengaruhi oleh factor-faktor lain yang tidak diteliti dalam pengamatan sederhana ini, Dilain pihak, secara parsial variabel keselamatan kerja $\left(\mathrm{X}_{1}\right)$ menghasilkan t hitung 4.259 lebih besar daripada $\mathrm{t}$ tabel (4.259>2.231) dengan tingkat signifikansi $0.00<0.05$, hal ini menunjukkan bahwa $\mathrm{Ho}_{1}$ ditolak dan $\mathrm{Ha}_{1}$ diterima, yang berarti secara parsial terdapat pengaruh signifikan antara variabel independen kesehatan $\left(\mathrm{X}_{1}\right)$ terhadap kinerja karyawan $(\mathrm{Y})$. Sedangkan variabel kesehatan kerja $\left(\mathrm{X}_{2}\right)$ menghasilkan t hitung 5.964 lebih besar daripada t tabel $(5.964>2.231)$ dengan tingkat signifikansi $0.00<0.05$, hal ini menunjukkan bahwa $\mathrm{Ho}_{2}$ ditolak dan $\mathrm{Ha}_{2}$ diterima, yang berarti secara parsial terdapat pengaruh signifikan antara variabel independen kesehatan $\left(\mathrm{X}_{2}\right)$ terhadap kinerja karyawan (Y).
\end{abstract}

Kata kunci: Kesehatan kerja, Keselamatan kerja dan Produktitas kerja.

\section{PENDAHULUAN}

\section{Latar Belakang Masalah}

Dewasa ini perusahaan yang mampu bertahan adalah perusahaan yang menyadari akan adanya persaingan dari berbagai pihak dengan berbagai dinamika perubahan dan perkembangan konsep inovasi baru. Dengan adanya persaingan industri yang semakin tajam menuntut setiap perusahaan mampu memanfaatkan 
setiap sumber daya manusia yang tersedia menghasilkan produk yang berdaya saing dan berkualitas tinggi. Tuntutan sebuah kualitas produk yang dihasilkan oleh setiap karya tidak bisa dipisahkan dari kemampuan dan peranan yang dimiliki oleh setiap sumber daya manusia (SDM) yang dimiliki oleh perusahaan tersebut. Adapun faktor pendukung dalam proses produktivitas kerja yang dimiliki oleh perusahaan dalam bentuk besarnya jumlah modal, jumlah dan kualitas mesin yang tersedia, atau berbagai bentuk dan jenis material lain baru mempunyai peranan dan manfaat apabila menunjang terlaksananya pelaksanaan kegiatan yang dilakukan oleh karyawan sebagai tenaga sumber daya manusia. Namun demikian sumber daya manuaia sebagai pelaku dalam melaksankan kegiatan kerja tentu saja tidak bisa terpisah dari berbagai permasalahan yang setiap saat bersentuhan langsung dengan kesehatan dan keselamatan kerja mereka selama melaksanakan tugas kegiatan sebagai karyawan.

Sebagaimana hasil analisa yang telah dilakukan oleh badan dunia International Labour Organization (ILO) telah menghasilkan sebuah kesimpulan bahwa, setidaknya orang telah meninggal rata-rata sebanyak 6000 orang yang terjadi setiap hari, yang berarti setiap 15 detik penduduk dunia berkurang satu orang karena kecelakaan kerja atau setiap tahun penduduk dunia berkurang sebanyak 2,200.000 orang meninggal yang disebabkan oleh karena kecelakaan yang berhubungan dengan pekerjaan mereka. Dari pernyataan ILO tersebut mengindikasikan bahwa kaum pria yang meninggal akibat kecelakaan dalam bekerja dipastikan dua kali lebih banyak apabila dibandingkan dengan kaum wanita karena kaum pria dalam melakukan berbagai pekerjaan jauh lebih bersentuhan dengan kegiatan yang beresiko tingkat bahayanya. Apabila dikalkulasi secara menyeluruh, kecelakaan karyawan yang terjadi di tempat kerja dan telah merenggut nyawa mereka sebanyak 350.000 orang, sementara sisanya meninggal dunia yang disebabkan oleh sakit yang diderita selama menjalankan pekerjaan-pekerjaan bahaya seperti membongkar zat kimia beracun (ILO, 2003 dalam Suardi, 2005). Bahkan biaya untuk kematian dan kecelakaan kerja diperkirakan mencapai \$ 119 milliar (Manuel G.Velasquez, 2005).

Program Keselamatan dan Kesehatan Kerja (K3) merupakan sebuah fasilitas yang dirancang berdasarkan kesepakatan dengan mempertimbangkan kepentingan keselamatan para karyawan yang disetujui oleh pengusaha sebagai upaya mencegah timbulnya kecelakaan dan penyakit yang diakibatkan oleh jenis pekerjaan yang mereka laksanakan, terutama mengantisipasi berbagai kegiatan yang berpotensi menimbulkan kecelakaan dan penyakit akibat kerja serta tindakan antisipatif apabila terjadi kecelakaan dan penyakit akibat kerja. Lebih lanjut program Kesehatan dan Keselamatan Kerja (K3) dirancang dengan tujuan agar mengurangi biaya perusahaan dengan mengantisipasi berbagai kemungkinan yang sewaktu-waktu terjadi pada setiap karyawan apabila terjadi kecelakaan di luar dugaan maupun berbagai penyakit yang diakibatkan oleh kinerja yang mereka lakukan.

Memperhatikan hal tersebut, maka program Kesehatan dan Keselamatan Kerja (K3) dalam rangka mencapai peningkatan produktivitas kerja adalah menjadi penting untuk dikaji lebih lanjut, karena kedua faktor tersebut sewaktu-waktu dapat mempengaruhi hasil produktivitas perusahaan dalam mencapai tujuan yang telah ditetapkan dalam pencapaian visi dan misi perusahaan. Berangkat dari pernyataan singkat tersebut, penulis terdorong melihat lebih jauh seberapa penting Pegaruh Kesehatan dan Keselamatan Kerja Karyawan terhadap Peningkatan Produktivitas Kerja karyawan Pada Orgaisasi. 


\section{Rumusan Masalah:}

Berdasarkan latar belakang masalah tersebut di atas, maka penulis dapat merumuskan beberapa masalah untuk dicarikan penyelesaianya yakni:

1. Apakah terdapat pegaruh yang positif dan signifikan antara keselamatan kerja terhadap Peningkatan Produktivitas kerja Karyawan pada Sebuah Organisasi secara parsial?

2. Apakah terdapat pengaruh positif dan signifikan antara kesehatan terhadap peningkatan produktivitas kerja karyawan pada sebuah organisasis secara parsial?

3. Apakah terdapatr pengaruh positif dan signifikan antara keselamatan dan kesehatan kerja terhadap produktivitas kerja karyawan pada sebuah organisasi secara simultan?

\section{Tujuan Penelitian}

Berdasarkan rumusan masalah tersebut dia atas, maka penulis merangkai tujuan dalam penulisan dapat disampai berikut:

1. Untuk mengetahui pegaruh antara keselamatan kerja terhadap Peningkatan Produktivitas kerja Karyawan pada Sebuah Organisasi secara parsial.

2. Untuk mengetahui pengaruh antara kesehatan terhadap peningkatan produktivitas kerja karyawan pada sebuah organisasis secara parsial.

3. Untuk mengetahui pengaruh antara keselamatan dan kesehatan kerja terhadap produktivitas kerja karyawan pada sebuah organisasi secara simultan.

\section{LANDASAN TEORI}

\section{Keselamatan Kerja}

Menurut Daryanto dalam Afrizal Firmanzah (2013;20) menjelaskan bahwa Keselamatan kerja adalah keselamatan yang berkaitan dengan peralatan, tempat kerja, lingkungan kerja, serta cara-cara melakukan pekerjaan. Demikian halnya pandangan Mangkunegara (2009:161) menjelaskan bahwa keselamatan kerja menunjukkan adanya kondisi yang aman atau selamat dari penderitaan, kerusakan atau kerugian di tempat kerja. Resiko keselamatan merupakan aspek-aspek dari lingkungan kerja yang dapat menyebabkan kebakaran, luka memar, keseleo, patah tulang, gangguan penglihatan dan pendengaran. Sementara pandangan Moenir (2016:203), menjelaskan bahwa hal-hal yang perlu diperhatikan terkait dengan keselamatan kerja antara lain beberapa indikator berikut: Perlindungan tenaga kerja yang meliputi: perlindungan keselamatan dan kesehatan serta lingkungan kerja. Keselamatan, kesehatan dan lingkungan kerja merupakan suatu upaya menciptakan kondisi yang aman dan bebas dari kecelakaan kerja, karena keselamatan dan kesehatan kerja berkaitan dengan resiko pekerjaan yang dilakukan. Oleh karena itu semakin tinggi resiko kerja, semakin tinggi pula ancaman kecelakaan yang dapat menimpanya.

Suma'mur (2000:1), menyatakan bahwa keselamatan kerja merupakan keselamatan yang bertalian dengan mesin, pesawat, alat kerja, bahan dan proses pengelolaannya, landasan tempat kerja dan lingkungannya serta cara-cara melakukan pekerjaan. Sementara kecelakaan adalah kejadian yang tidak terduga dan tidak diharapkan. Demikian halnya terkait dengan kecelakaan akibat kerja dapat diterjemahkan sebagai kecelakaan yang berhubungan dengan hubungan kerja pada perusahaan yang diakibatkan oleh kegiatan kerja pada waktu melaksanakan pekerjaan. Sebagai bentuk tanggung jawab perusahaan terhadap setiap karyawan, perusahaan perlu memperhatikan kesehatan mereka karena secara tidak langsung dapat meningkatkan produktivitas kerja para tenaga kerja, karena kesehatan tenaga kerja yang buruk akan berakibat pada menurunnya tingkat absensi yang tinggi dengan produktivitas yang rendah. Basir Barthos (195:140) menambahkan bahwa penyebab 
terbesar terjadinya kecelakaan kerja lebih dipengaruhi oleh kurangnya kesadaran pengusaha dan tenaga kerja sendiri terutama dalam melaksanakan peraturan perundangan yang ditetapkan. Dampak dari kurangnya kesadaran ats pentingnya perundang-undangan tersebut, banyak diantara para pengusaha kurang memahami pentingnya pemanfaatan akan pelaksanaan keselamatan dan kesehatan kerja bagi setiap karyawan, apalagi berpengaruh terhadap pengeluaran biaya oleh perusahaan menjadia alasan tersendiri untuk tidak menyediakan fasilitas program keselamatan dan kesehatan kerja. Sikap dan keputusan yang diambil oleh perusahaan dengan tidak memperhatikan pentingnya progran keselamatan dan kesehatan kerja tentu akan berpengaruh terhadap menurunnya loyalitas dan mutu produktivitas kerja karyawan yang cepat atau lambat akan menjadi masalah serius bagi perusahaan itu sendiri terutama untuk tetap bisa bertahan dan berkembang di masa yang akan datang.

Sebagaimana yang diungkapkan oleh Gary Dassler (1997:303) bahwa keselamatan dan pencegahan kecelakaan terhadap pelaksanaan kerja karyawan sepenuhnya menjadi tanggung jawab manajer karena tidak ada seorangpun dalam menjalankan kegiatan kerja menginginkan untuk terjadi kecelakaan. Menyadari pentingnya pencegahan terhadap kecelakaan kerja, maka seorang manajer harus mengantisipasi sedini mungkin dengan berbagai program untuk memberikan dan menumbuhkan rasa aman terhadap setiap karyawan dalam menjalankan pekerjaan.

\section{Kesehatan Kerja}

Mathis dan Jackson (2002:245), "mengartikan kesehatan kerja adalah merupakan kondisi yang merujuk pada kondisi fisik, mental, dan stabilitas emosi secara umum". Kemudian menurut Mangkunegara (2013:161,"keadaan sehat, baik secara fisik, mental, spiritual maupun sosial yang memungkinkan setiap orang untuk hidup produktif secara sosial dan ekonomis". Tujuan Kesehatan Kerja menurut Nuraini (2012) yaitu : 1. Memelihara dan meningkatkan derajat kesehatan masyarakat pekerja di semua lapangan pekerjaan ketingkat yang setinggitingginya, baik fisik, mental maupun kesehatan sosial. 2. Mencegah timbulnya gangguan kesehatan masyarakat pekerja yang diakibatkan oleh tindakan/kondisi lingkungan kerjanya. 3. Memberikan perlindungan bagi pekerja dalam pekerjaannya dari kemungkinan bahaya yang disebabkan oleh faktor-faktor yang membahayakan kesehatan. 4. Menempatkan dan memelihara pekerja di suatu lingkungan pekerjaan yang sesuai dengan kemampuan fisik dan psikis pekerjaannya. Kesehatan kerja mempengaruhi manusia dalam hubungannya dengan pekerjaan dan ingkungan kerjanya. Baik secara fisik maupun psikis yang meliputi : metode bekerja, kondisi kerja dan lingkungan kerja yang mungkin dapat menyebabkan kecelakaan, penyakit ataupun perubahan dari kesehatan seseorang.

Melengkapi pendapat lain, Soedjono menyampaikan bahwa tujuan program keselamatan dan kesehatan kerja antara lain: 1). Melindungi tenaga kerja atas hak keselamatannya dalam melakukan pekerjaan; 2). Menjamin keselamatan setiap orang yang berada di lokasi kerja; 3). Sumber produksi dipelihara dan dipergunakan secara aman dan efisien.

Dari beberapa pendapat diatas dapat disimpulkan bahwa program keselamatan kerja merupakan tugas semua orang yang bekerja. Keselamatan kerja adalah dari, oleh dan untuk setiap tenaga kerja serta orang lain termasuk masyarakat umum. Apabila suatu organisasi kurang memperhatikan masalah pentingnya terhadap keselamatan dan kesehatan kerja karyawan, dampak yang paling sering terjadi antara lain banyak karyawan yang mengalami kecelakaan dan sakit namun tidak mendapat perhatian dari perusahaan untuk embantu pengobatan. Untuk itu perusahaan harus menyadari bahwa 
program keselamatan dan kesehatan kerja adalah mutlak penting untuk diperhatikan dan ditetapkan sehingga organisasi dengan sumber daya manusia yang berada dibawah perlindungannya merasa nyaman untuk bekerja dan mampu menciptakan kinerja secara efektif dan efisien.

\section{Pengertian Produktivitas Kerja}

Produktivitas dalam pandangan menurut ilmu ekonomi sering diartikan sebagai rasio dari hasil kegiatan antara output (keluaran) dengan segala pengorbanan (biaya) untuk mewujudkan hasil input (pemasukan). Pada umumnya rasio lebih berhubungan dengan bilangan rata-rata yang menggunakan hasil bagi antara angka keluaran total dan angka masukan total dari beberapa kategori produk, diantaranya menyangkut biaya bahan baku dan tenaga kerja. Pada dasarnya setiap bentuk masukan total apabila dikuantifikasikan dapat digunakan sebagai faktor pembagi pada rasio produktivitas.

Dalam Rome Conference European Producticity Agency (1958) dijelaskan bahwa produktivitas adalah tingkat efisiensi dan efektivitas dari penggunaan elemen produksi. Dengan pernyataan tersebut menunjukkan bahwa bicara produktivitas adalah bicara tentang sikap mental yang selalu mencari perbaikan terhadap apa yang telah ada. Suatu keyakinan bahwa seseorang dapat melakukan pekerjaan lebih baik hari ini daripada kegiatan yang telah dilakukan pada masa lalu, demikian halnya keyakinan bahwa masa depan harus dibangun dan ditata jauh lebih baik daripada masa kini dan masa lalu.

Dewan Produktivitas Nasional RI (1983) telah merumuskan terhadap hakekat produktivitas sebagaiu sikap mental yang selalu mempunyai pandangan bahwa mutu kehidupan hari ini harus jauh lebih baik daripada kemarin demikian halnya hari esok harus jauh lebih baik daripada hari ini. Secara umum produktivitas pengertian perbandingan atau rasio antara hasil yang dicapai dengan keseluruhan sumber daya yang digunakan. Produksi dan produktivitas merupakan dua pengertian yang berbeda. Peningkatan produksi menunjukkan pertambahan jumlah hasil yang dicapai, sedangkan peningkatan produksi tidak selalu disebabkan oleh peningkatan produktivitas, karena produksi dapat meningkat walaupun produktivitasnya tetap ataupun menurun. Peningkatan produktivitas dapat dilihat dalam tiga bentuk yakni jumlah produksi meningkat dengan menggunakan sumber daya yang sama; jumlah produksi yang sama atau meningkat dicapai dengan menggunakan sumber daya yang lebih sedikit; dan jumlag produksi yang jauh lebih besar diperoleh dengan pertambahan sumber daya yang relatif lebih kecil.

Sumber daya manusia memegang peranan utama dalam proses peningkatan produktivitas, karena alat produksi dan teknologi pada hakikatnya merupakan hasil dari manusia. Produktivitas tenaga kerja mengandung pengertian perbandingan antara hasil yang dicapai dengan peran-peran tenaga kerja per satuan waktu. Produktivitas tenaga kerja dipengaruhi oleh berbagai faktor baik secara langsung ataupu tidak langsung atau yang berhubungan dengan tenaga kerja maupun sendiri serta faktorfaktor lainnya, seperti pendidikan, ketrampilan, disiplin, sikap dan etika kerja, motivasi, gizi dan kesehatan, tingkat penghasilan jaminan sosial, lingkungan dan iklim kerja, hubungan industrial Pancasila, manajemen, kesempatan erja, dan kesempatan berprestasi. Peningkatan produktivitas tenaga kerja merupakan pembaruan pandangan hidup dan kultural dengan sikap mental tenaga kerja serta perluasan upaya untuk meningkatkan mutu kehidupan masyarakat. 


\section{Kerangka Pemikiran}

Pada dunia kerja adanya faktor yang mempengaruhi keselamatan, keamanan, kesehatan kerja yang diantaranya berupa faktor dari diri tenaga kerja sendiri, biasanya tenaga kerja yang sudah lama bekerja tidak memperdulikan keselamatan akan dirinya. Mereka berpikir dengan menggunakan alat perlindungan diri dalam keselamatan diri, bahkan justru akan mengganggu dalam menjalankan pekerjaan sehingga mereka tidak terlalu memikirkan bahaya yang akan terjadi atau yang biasa disebut sebagai tindakan perbuatan manusia yang tidak memenuhi keselamatan.

Disisi lain sebenarnya penarapan Keselamatan dan Kesehatan Kerja justru akan memberikan sebuah jaminan positif terhadap pelaksanaan tugas agar bisa berlangsung dengan baik tanpa adanya kecelakaan yang tidak diinginkan dan dengan sendirinya akan meningkatkan produktifitas kerja karayawan itu sendiri. Adapun kerangka pemikiran terkait pentingnya Keselamatan dan Kesehatan Kerja teradap Produktivitas kerja Karyawan dapat digambarkan dalam diagram berikut.

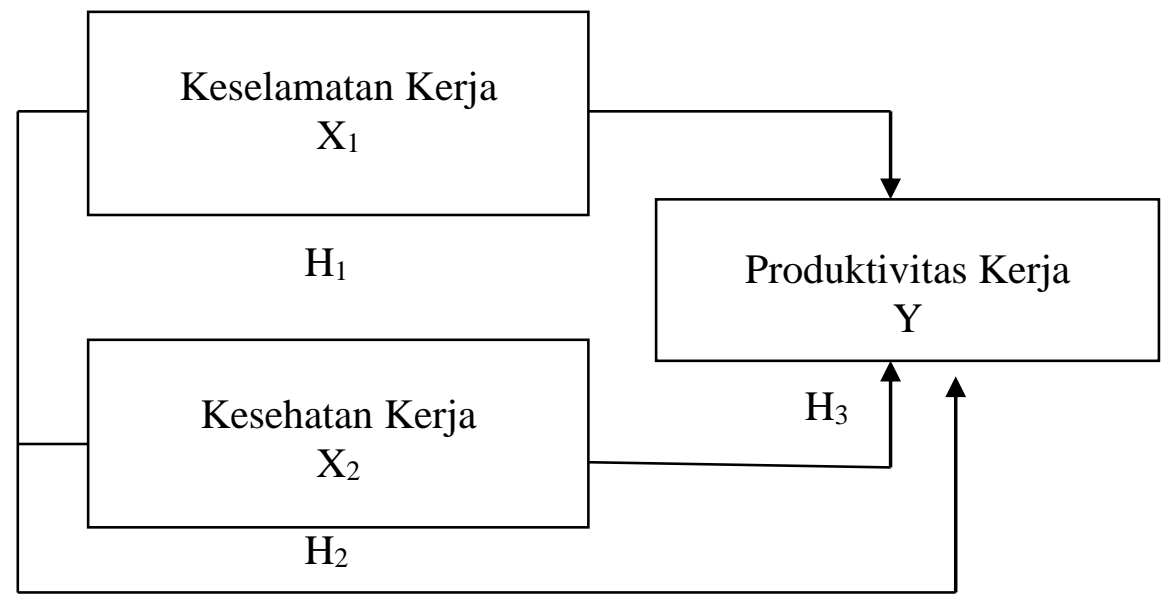

\section{Hipotesis}

Berdasarkan pada rumusan masalah, tujuan penelitian, dan kerangka pemikiran yang telah dijelaskan, hipotesis dalam penelitian ini adalah sebagai berikut:

$\mathrm{H}_{01}$ : Keselamatan tidak berpengaruh terhadap produktivitas kerja karyawan.

$\mathrm{Ha}_{1}$ : Keselamatan berpengaruh terhadap produktivitas kerja karyawan.

$\mathrm{H}_{02}$ : Kesehatana tidak tidak berpengaruh terhadap produktivitas kerja karyawan.

$\mathrm{Ha}_{2}$ : Kesehatan berpengaruh terhadap produktivitas kerja karyawan.

$\mathrm{H}_{03}$ : Kesehatana dan Keselamatan Kerja tidak tidak berpengaruh terhadap produktivitas kerja karyawan.

$\mathrm{Ha}_{3}$ : Kesehatan dan Keselamatan Kerja berpengaruh terhadap produktivitas kerja karyawan.

\section{METODOLOGI PENELITIAN}

Untuk menunjang tulisan ini, penulis mendekati dengan jenis penelitian yang dikategorikan sebagai penelitian eksplanasi atau penjelasan (explanatory research) dengan pendekatan kuantitatif, dengan jumlah sampel sebanyak 77 dengan pendekatan pengambilan sampel menggunakan teknik sampling jenuh, karena sampling jenuh merupakan teknik penentuan sampel yang digunakan apabila populasi 
memiliki jumlah yang kecil atau kurang dari 100 orang. Metode analisis data yang digunakan dalam penelitian ini adalah :

\section{Analisis Deskriptif}

Menurut Sugiyono (2013:207), "Analisis Deskriptif adalah statistik yang digunakan untuk menganalisis data dengan cara mendiskripsikan atau menggambarkan data yang telah terkumpul sebagaimana adanya tanpa bermaksud membuat kesimpulan yang berlaku untuk umum atau generalisasi”. Analisis dalam penelitian ini digunakan untuk mendeskripsikan variabel keselamatan dan kesehatan kerja dan kinerja karyawan dengan jalan mendistribusikan items dari masing-masing variabel. Setelah seluruh data terkumpul selanjutnya mengolah data dan mentabulasikan ke dalam tabel, kemudian membahas data yang telah diolah tersebut secara deskriptif. Ukuran deskriptifnya adalah dengan memberikan angka baik dalam jumlah responden maupun dalam angka persentase.

\section{Uji Validitas dan Reliabilitas Kuesioner}

Validitas adalah ketepatan atau kecermatan suatu instrument dalam mengukur apa yang ingin diukur. Pengujian menggunakan uji dua sisi dengan taraf signifikansi 0,05 dengan kriteria pengujian:

- Jika $\mathrm{r}$ hitung > $\mathrm{r}$ tabel, maka instrument berkorelasi signifikan terhadap skor total, sehingga dinyatakan valid.

- $\quad$ Jika $r$ hitung < $r$ tabel, maka instrument tidak berkorelasi signifikan terhadap skor total, sehingga dinyatakan tidak valid.

Uji Reliabilitas Kuesioner adalah digunakan untuk mengetahui konsistensi alat ukur, apakah alat pengukur yang digunakan dapat diandalkan dan tetap konsisten jika pengukuran tersebut diulang. Sebuah hasil dikatakan reliable apabila nilai alpha lebih besar dari r kritis product moment, sebuah hasil dikatakan reliabel apabila crombact alpha $>06$. Sebaliknya sebuah hasil dikatakan tidak reliable apabila crombact alpha $<$ 06.
Analisi Regresi Linear Berganda berganda adalah sebagai berikut:
$\mathrm{Y}=\mathrm{a}=\mathrm{b}_{1} \mathrm{X}_{1}+\mathrm{b}_{2} \mathrm{X}_{2}+\mathrm{b}_{\mathrm{n}} \mathrm{X}_{\mathrm{n}}$
$\mathrm{Y} \quad=$ variabel dependen
$\mathrm{X}_{1} \mathrm{X}_{2}=$ variabel independen
$\mathrm{a} \quad=$ konstanta (nilai $\mathrm{Y}$ apabila $\mathrm{X}_{1} \mathrm{X}_{2} \ldots \mathrm{Xn}=0$ )

Anaslisa regresi linier berganda merupakan hubungan secara linier antara dua atau lebih variabel independen (X) denganvariabel dependen (Y). Adapun analisa tersebut digunakan untuk mengetahui arah hubungan antara variabel independen berhubungan positif atau negatif dan untuk memprediksi nilai dari variabel dependen apabila nilai variabel independen mengalami kenaikan atau penurunan. Persamaan regresi linier

Uji Koefisien Regresi Secara Parsial (Uji t).

Uji t digunakan untuk mengetahui apakah variabel independen $\left(\mathrm{X}_{1}, \mathrm{X}_{2} \ldots . \mathrm{Xn}\right)$ secara parsial berpengaruh signifikan terhadap variabel dependen (Y).Jika $t$ hitung $>t$ tabel, maka Ho ditolak dan Ha diterima, yang berarti secara parsial terdapat pengaruh secara signifikan antara variabel independen (X) terhadap variabel dependen (Y). Sebaliknya apabila $\mathrm{t}$ hitung $<\mathrm{t}$ tabel, maka Ho diterima, dan Ha ditolak yang berarti tidak 
terdapat pengaruh secara signifikan antara variabel independen (X) terhadap dependen (Y)..

\section{Uji Regresi Linier Secara Bersama-sama (Uji F).}

Uji ini digunakan untuk mengetahui apakah variabel independen $(\mathrm{X} 1, \mathrm{X} 2 \ldots \mathrm{Xn})$ secara bersama-sama berpengaruh secara signifikan terhadap variabel dependen (Y). Apabila $\mathrm{F}$ hitung > F tabel, maka Ho ditolak, dan Ha diterima yang berarti terdapat pengaruh secara signifikan antara $\mathrm{X}_{1}$ dan $\mathrm{X}_{2}$ terhadap $\mathrm{Y}$. Sebaliknya apabila $\mathrm{F}$ hitung $<\mathrm{F}$ tabel, maka Ho diterima, dan $\mathrm{Ha}$ ditolak yang berarti tidak terdapat pengaruh secara signifikan antara $\mathrm{X}_{1}$ dan $\mathrm{X}_{2}$ terhadap $\mathrm{Y}$.

\section{Analisa Determinasi $\left(\mathbf{R}^{2}\right)$}

Analisa determinasi dalam regresi linier berganda digunakan untuk mengetahui prosentase sumbangan pengaruh variabel independen $\left(\mathrm{X}_{1}, \mathrm{X}_{2} \ldots \mathrm{Xn}\right)$ secara serentak terhadap variabel dependen ( $\mathrm{Y})$. Mengingat variabel $\mathrm{X}$ yang ditinjau oleh penulis lebih dari satu, maka penulis menggunakan adjusted $\mathrm{R}$ Square, hal ini sesuai dengan padangan Santoso (2001) yang menyatakan bahwa apabila dalam regresi menggunakan lebih dari dua variabel independen, maka yang digunakan adalah adjusted $\mathrm{R}^{2}$ sebagai koefisien determinasi.

\section{PEMBAHASAN DAN ANALISIS}

\section{Uji Validitas dan Reliabilitas Kuesioner}

Uji validitas dilakukan untuk mengetahui sejauh mana kesesuaian dan kecepatan alat ukur dalam bentuk instrumen pertanyaan yang diajukan dalam menilai suatu obyek yang diamati. Uji validitas dilakukan dengan menggunakan rumus korelasi Pearson Product Moment dan hasilnya akan dibandingkan dengan nilai angka kritik tabel korelasi nilai r. Sebagai penelitian awal, kuesioner disebarkan kepada 30 orang responden. Setelah dilakukan uji validitas, didapat 30 pertanyaan yang memadai, berarti seluruh instrumen dinyatakan memenuhi syarat untuk diolah lebih lanjut. Dengan mengacu pada tingkat signifikan sebesar 0,3 ( $\left.\mathrm{r}_{\mathrm{s}} \mathrm{kritis}\right)$, maka apabila $\mathrm{r}$ korelasi $<0,3$ berarti pernyataan tidak valid, sementara apabila $\mathrm{r}_{\mathrm{s}}$ korelasi $>$ 0,3 berarti pernyataan dinyatakan valid pada taraf kepercayaan 95\% ( Sugiyono: 2009). Berdasarkan hasil perhitungan uji validitas instrumen untuk Keselamatan dan Kesehatan Kerja (K3) sebagai variabel $\mathrm{X}$ serta peningkatan produktivitas kerja karyawan sebagai variabel Y dengan menggunakan korelasi rank Spearman dapat dijelaskan bahwa.

Uji Validitas Instrumen Kesehatan sebagai Variabel $\mathrm{X}_{1}$

\begin{tabular}{|c|c|c|c|}
\hline $\begin{array}{c}\text { No } \\
\text { Instrumen }\end{array}$ & Rs hitung & Rs Kritis & Keterangan \\
\hline 1 & 0,84 & 0,3 & Valid \\
\hline 2 & 0,48 & 0,3 & Valid \\
\hline 3 & 0,65 & 0,3 & Valid \\
\hline 4 & 0,78 & 0,3 & Valid \\
\hline 5 & 0,58 & 0,3 & Valid \\
\hline 6 & 0,84 & 0,3 & Valid \\
\hline 7 & 0,80 & 0,3 & Valid \\
\hline 8 & 0,84 & 0,3 & Valid \\
\hline
\end{tabular}




\begin{tabular}{|c|c|c|c|}
\hline 9 & 0,61 & 0,3 & Valid \\
\hline 10 & 0,73 & 0,3 & Valid \\
\hline
\end{tabular}

Berdasarkan hasil uji validitas tersebut dapat disimpulkan bahwa semua pernyataan instrumen Kesehatan sebagai variabel $X_{1}$ adalah valid yang selanjutnya dapat digunakan dalam pengolahan analisis data, karena semua hasil korelasi setiap item menghasilkan nilai $r_{s}$ hitung $>r_{s}$ kritis, sehingga validitas dalam variabel $X_{1}$ terpenuhi.

Uji Validitas Instrumen Keselamatan Kerja sebagai Variabel $\mathrm{X}_{2}$

\begin{tabular}{|c|c|c|c|}
\hline $\begin{array}{c}\text { No } \\
\text { Instrumen }\end{array}$ & Rs hitung & Rs Kritis & Keterangan \\
\hline 1 & 0,76 & 0,3 & Valid \\
\hline 2 & 0,58 & 0,3 & Valid \\
\hline 3 & 0,65 & 0,3 & Valid \\
\hline 4 & 0,68 & 0,3 & Valid \\
\hline 5 & 0,68 & 0,3 & Valid \\
\hline 6 & 0,64 & 0,3 & Valid \\
\hline 7 & 0,80 & 0,3 & Valid \\
\hline 8 & 0,84 & 0,3 & Valid \\
\hline 9 & 0,71 & 0,3 & Valid \\
\hline 10 & 0,73 & 0,3 & \\
\hline
\end{tabular}

Berdasarkan hasil uji validitas tersebut dapat disimpulkan bahwa semua pernyataan instrumen Keselamatan sebagai variabel $\mathrm{X}_{2}$ adalah valid yang selanjutnya dapat digunakan dalam pengolahan analisis data, karena semua hasil korelasi setiap item menghasilkan nilai $r_{s}$ hitung $>r_{s}$ kritis, sehingga validitas dalam variabel $X_{2}$ terpenuhi.

Uji Validitas Instrumen Produktivitas Kerja Karyawan sebagai Variabel Y

\begin{tabular}{|c|c|c|c|}
\hline $\begin{array}{c}\text { No } \\
\text { Instrumen }\end{array}$ & Rs hitung & Rs Kritis & Keterangan \\
\hline 1 & 0,61 & 0,3 & Valid \\
\hline 2 & 0,76 & 0,3 & Valid \\
\hline 3 & 0,56 & 0,3 & Valid \\
\hline 4 & 0,69 & 0,3 & Valid \\
\hline 5 & 0,61 & 0,3 & Valid \\
\hline 6 & 0,72 & 0,3 & Valid \\
\hline 7 & 0,71 & 0,3 & Valid \\
\hline 8 & 0,77 & 0,3 & Valid \\
\hline 9 & 0,63 & 0,3 & Valid \\
\hline 10 & 0,67 & 0,3 & \\
\hline
\end{tabular}

Berdasarkan hasil uji validitas tersebut dapat disimpulkan bahwa semua pernyataan instrumen Peningkatan Produktivitas Kerja karyawan variabel Y adalah valid yang selanjutnya dapat digunakan dalam pengolahan analisis data, karena semua hasil korelasi setiap item menghasilkan nilai $r_{s}$ hiutung $>r_{s}$ kritis, sehingga validitas dalam variabel Y terpenuhi.

Sementara uji reliabilitas dilakukan dengan tujuan untuk mengetahui sejauh mana suatu hasil pengukuran instrumen relatif konsisten, apabila instrumen tersebut digunakan lagi sebagai alat ukur suatu objek atau responden. Uji reliabilitas dilakukan 
dengan menggunakan rumus Cronbach's Alpha. Dari hasil perhitungan didapatkan 0,93 untuk faktor keselamatan sebesar 0.87 sedangkan 0,85 untuk produktivitas kerja karyawan. Nilai yang diperoleh lebih besar dari 0,60, maka kuesioner yang disebarkan dapat diandalkan (reliabel) untuk dijadikan alat ukur pada penelitian ini.

Uji Regresi Linier Berganda

\section{Coefficients}

\begin{tabular}{|c|c|c|c|c|c|}
\hline Model & \multicolumn{2}{|c|}{$\begin{array}{l}\text { Unstandardized } \\
\text { Coefficients }\end{array}$} & $\begin{array}{c}\text { Standardi } \\
\text { zed } \\
\text { Coefficie } \\
\text { nts }\end{array}$ & $\mathrm{t}$ & Sig \\
\hline (Constant) & 4662.491 & 668.382 & & 6.976 & .000 \\
\hline $\operatorname{Kesehatan}\left(\mathrm{X}_{1}\right)$ & 46.482 & 59.161 & 1.146 & 4.259 & .001 \\
\hline $\operatorname{Keselamatan}\left(\mathrm{X}_{2}\right)$ & 692.107 & 116.049 & 1.012 & 5.964 & 000 \\
\hline
\end{tabular}

$$
\begin{array}{ll}
\mathrm{Y} & =\mathrm{a}+\mathrm{b}_{1} \mathrm{X}_{1}+\mathrm{b}_{2} \mathrm{X}_{2} \\
\mathrm{Y} & =4662.491+\left(46.482 \mathrm{X}_{1}+692.107 \mathrm{X}_{2}\right) \\
\mathrm{Y} & =4662.491+46.482 \mathrm{X}_{1}+692.107 \mathrm{X}_{2}
\end{array}
$$

Keterangan:

$\mathrm{Y} \quad=$ Produktivitas kerja karyawan

a $\quad=$ konstanta

$\mathrm{b}_{1} \mathrm{~b}_{2} \quad=$ koefisien regresi

$\mathrm{X}_{1} \quad=$ Kesehatan

$\mathrm{X}_{2} \quad=$ Keselamatan kerja

Persamaan regresi tersebut dapat dijelaskan bahwa: konstanta sebesar 4662.491, berarti jika kesehatan $\left(\mathrm{X}_{1}\right)$ dan Keselamatan kerja $\left(\mathrm{X}_{2}\right)$ nilainya adalah 0, maka produktivitas Kerja karyawan (Y) nilainya sebesar 4662.491. Koefisien regresi variabel $\mathrm{X}_{1}$ sebesar 46.482, berarti apabila variabel independen lain nilainya tetap dan Kesehatan $\left(\mathrm{X}_{1}\right)$ mengalami kenaikan 1 poin, maka produktivitas kerja karyawan $(\mathrm{Y})$ akan mengalami kenaikan sebesar 46.482. Koefisien bernilai positif yang berarti terjadi hubungan positif antara kesehatan $\left(\mathrm{X}_{1}\right)$ dengan Produktifitas kerja karyawan (Y). Semakin naik kesehatan kerja karyawan akan semakin meningkat juga produktivitas kerja karyawan. Demikian halnya dengan keselamatan kerja karyawan $\left(\mathrm{X}_{2}\right)$, Koefisien regresi variabel keselamatan $\left(\mathrm{X}_{2}\right)$ sebesar 46482 , berarti apabila variabel independen lain nilainya tetap dan Kesehatan $\left(\mathrm{X}_{1}\right)$ mengalami kenaikan 1 poin, maka produktivitas kerja karyawan (Y) akan mengalami kenaikan sebesar 692.107. Koefisien bernilai positif yang berarti terjadi hubungan positif antara keselamatan $\left(\mathrm{X}_{2}\right)$ dengan Produktifitas kerja karyawan (Y). Semakin naik keselamatan kerja karyawan akan semakin meningkat juga produktivitas kerja karyawan.

\begin{tabular}{|c|c|c|c|c|c|}
\hline Model & $\begin{array}{r}\text { Unsta } \\
\text { Coe }\end{array}$ & $\begin{array}{l}\text { lardized } \\
\text { icients }\end{array}$ & $\begin{array}{l}\text { Standardi } \\
\text { zed } \\
\text { Coefficie } \\
\text { nts }\end{array}$ & $\mathrm{t}$ & Sig \\
\hline $\begin{array}{l}\text { (Constant) } \\
\text { Kesehatan }\left(\mathrm{X}_{1}\right) \\
\text { Keselamatan }\left(\mathrm{X}_{2}\right)\end{array}$ & $\begin{array}{l}4662.491 \\
.74 .482 \\
692.107 \\
\end{array}$ & $\begin{array}{l}668.382 \\
59.161 \\
116.049 \\
\end{array}$ & $\begin{array}{l}1.146 \\
1.012 \\
\end{array}$ & $\begin{array}{l}6.976 \\
4.259 \\
5.964 \\
\end{array}$ & $\begin{array}{l}.000 \\
.000 \\
000 \\
\end{array}$ \\
\hline
\end{tabular}

\section{Uji Parsial (Uji t)}

\section{Coefficients}


Berdasarkan $\&=5 \%: 2=2.5 \%$ (uji 2 sisi) dengan derajat kebebasan (df) n-k-1 atau 18-2-1 =15, dengan pegujian 2 sisi (signifikansi - 0,025) hassil diperoleh ntk t tabel sebesar 2.131.

Berdasarkan hasil perhitungan, ditemukan bahwa variabel kesehatan $\left(\mathrm{X}_{1}\right)$ diperoleh hasil $t$ hitung $>\mathrm{t}$ tabel $(4.259>2.131)$ dengan tingkat signifikansi $0,000<0,05$, yang berarti Ho ditolak dan Ha diterima, sehingga dapat disimpulkan bahwa secara parsial kesehatan $\left(\mathrm{H}_{1}\right)$ berpengaruh secara signifikan terhadap produktifitas kerja karyawan.

Demikian halnya variabel keselamatan kerja $\left(\mathrm{X}_{2}\right)$ diperoleh hasil $\mathrm{t}$ hitung $>\mathrm{t}$ tabel $(5.964>2.131)$ dengan tingkat signifikansi $0,000<0,05$, yang berarti Ho ditolak dan Ha diterima, sehingga dapat disimpulkan bahwa secara parsial keselamatan kerja $\left(\mathrm{H}_{2}\right)$ berpengaruh secara signifikan terhadap produktifitas kerja karyawan.

\section{Uji Simultan (Uji F)}

\begin{tabular}{|rl|r|r|r|r|r|}
\hline \multicolumn{1}{|c|}{ Model } & \multicolumn{1}{c|}{$\begin{array}{c}\text { Sum of } \\
\text { Squares }\end{array}$} & \multicolumn{1}{c|}{ df } & \multicolumn{1}{c|}{$\begin{array}{c}\text { Mean } \\
\text { Square }\end{array}$} & F & Sig. \\
\hline \multirow{2}{*}{1} & Residual & .537 & 2 & .268 & 23.365 & .000 \\
\cline { 3 - 5 } & 1.964 & 15 & .034 & & \\
\hline & Residual & 2.671 & 17 & & & \\
\hline
\end{tabular}

a. Dependent Variable: $Y$

b. b. Predictors: (Constant), $X_{.2}, X_{.1}$

Berdasarkan tabel tersebut dapat dijelaskan bahwa dengan menggunakan tingkat signifikansi sebesar 95\% dengan $\alpha$ sebesar 5\%, maka dapat disimpulkan bahwa $\mathrm{F}$ hitung > F tabel $(23.365>3.683)$, dengan tingkat signifikansi $0,000<0,05$, yang berarti Ho ditolak dan Ha diterima, hal ini dapat dijelaskan bahwa secara bersamasama variabel independen (kesehatan dan keselamatan kerja) berpengaruh terhadap variabel dependen (produktifitas kerja karyawan).

\section{Hasil Koefisien Determinasi}

a. Predictors: (Constant), X.2, X.1

b. Dependent Variable: $Y$

Berdasarkan hasil tersebut diatas, diperoleh angka $\mathrm{R}^{2}$ (R Square) sebesar 0,776 atau $77,6 \%$. hal ini menunjukkan bahwa presentase sumbangan pengaruh variabel independen (kesehatan dan keselamatan kerja) terhadapm variabel dependen (produktivitas kerja) adalah sebesar $77.6 \%$, sementara sisanya sebesar $12.4 \%$ dipengaruhi oleh factor-faktor lain yang tidak diteliti dalam pengamatan sederhana ini. Adapun Adjusted R Square sebesar 0,741 atau 74,1\% hal ini menunjukkan bahwa presentase sumbangan pengaruh variabel independen (kesehatan dan keselamatan kerja) terhadapm variabel dependen (produktivitas kerja) adalah sebesar $74.1 \%$, sementara sisanya sebesar $25.9 \%$ dipengaruhi oleh factor-faktor lain yang tidak diteliti dalam pengamatan sederhana ini, 


\section{Kesimpulan}

\section{KESIMPULAN DAN SARAN}

Berdasarkan hasil ulasan tersebut di atas, dapat disimpulkan bahwa organisasi perlu memperhatikan pentingnya kesehatan dan keselamatan kerja bagi setiap karyawan, terlebih bagi karyawan yang berhubungan langsung dengan pekerjaan yang bersentuhan terhadap keselamatan kerja. Oleh karena itu beberapa kesimpulan dapat disampaikan bahwa:

1. Hasil perhitungan, ditemukan bahwa variabel kesehatan $\left(\mathrm{X}_{1}\right)$ diperoleh hasil $\mathrm{t}$ hitung $>\mathrm{t}$ tabel $(4.259>2.131)$ dengan tingkat signifikansi $0,000<0,05$, yang berarti Ho ditolak dan Ha diterima, sehingga dapat disimpulkan bahwa secara parsial kesehatan $\left(\mathrm{H}_{1}\right)$ berpengaruh secara signifikan terhadap produktifitas kerja karyawan.

2. Demikian halnya variabel keselamatan kerja $\left(\mathrm{X}_{2}\right)$ diperoleh hasil $\mathrm{t}$ hitung $>\mathrm{t}$ tabel $(5.964>2.131)$ dengan tingkat signifikansi $0,000<0,05$, yang berarti Ho ditolak dan Ha diterima, sehingga dapat disimpulkan bahwa secara parsial keselamatan kerja $\left(\mathrm{H}_{2}\right)$ berpengaruh secara signifikan terhadap produktifitas kerja karyawan.

3. Sementara berdasarkan hasil Uji F, secara simultan dapat dapat disimpulkan bahwa $\mathrm{F}$ hitung $>\mathrm{F}$ tabel $(23.365>3.683)$, dengan tingkat signifikansi $0,000<$ 0,05, yang berarti Ho ditolak dan Ha diterima, hal ini dapat dijelaskan bahwa secara bersama-sama variabel independen (kesehatan dan keselamatan kerja) Saran berpengaruh terhadap variabel dependen (produktifitas kerja karyawan).

Beragkat dari beberapa kesimpulan diatas dapat dikemukakan beberapa saran yang diharapkan dapat bermanfaat bagi perusahaan maupun bagi pihak-pihak lain. Adapun saran yang diberikan antara lain :

1. Dari hasil ulasan di atas, beberapa hal yang harus diperhatikan oleh organisasi sebagai pengguna tenaga kerja adalah upaya menciptakan lingkungan kerja yang kondusif sehingga karyawan merasa nyaman dalam bekerja dalam upaya mencapai tujuan organisasi secara menyeluruh yakni tercapainya kenerja secara maksimal tanpa berpikir akan adanya resiko kecelakaan selama bekerja.

2. Hal penting yang harus diperhatikan secara khusus adalah kondisi kesehatan karyawan dengan cara memberikan pemeliharaan kesehatan tenaga kerja yang mencakup jaminan kesehatan, pelayanan kesehatan dan pemeriksaan tenaga kerja kepada setiap karyawan, sehingga tanpa harus diawasi sekalipun, kinerja karyawan dengan sendirinya dapat meningkat karena setiap karyawan mendapat pemeliharaan kesehatan tenaga kerja.

\section{DAFTAR PUSTAKA}

Cascio, W.F. 2008. Managing Human Resources - Productivity Quality of Work Life, Profits. Edisi ke-5. McGraw-Hill, Amerika Serikat.

Cresswell, John W. 2008. Educational Research.Planning, Conduction, and Evaluation Qualitative \& Quantitative Approaches.London. Sage Publications.

Daryanto, D. 2003. Keselamatan dan Kesehatan Kerja Bengkel. Jakarta: PT Bima Adiaksara dan PT Rineka Cipta.

Dessler, G. 2014. Manajemen Sumber Daya Manusia. PT Gramedia Pustaka Utama, Jakarta. 
Dharma, Agus, 2003. Manajemen Supervisi,Cetakan Kelima. Jakarta: PT Raja Grafindo Persada.

Flippo, E. B. 2004. Manajemen Personalia. Terjemahan. Penerbit Erlangga, Jakarta. Hasibuan, Malayu S.P. 2009. Manajemen Sumber Daya Manusia. Edisi Revisi. Jakarta: PT Bumi Aksara.

Husni, Lalu. 2005. Hukum Ketenagakerjaan. Edisi Revisi. Jakarta: PT. Raja Grafindo.

Ilham. 2002. Analisis Hubungan Kesehatan dan Keselamatan Kerja (K3) dengan Motivasi Kerja Karyawan di PT. Good Year Indonesia. Fakultas Teknologi Pertanian, Institut Pertanian Bogor, Bogor.

Luthans, Fred. 2006. Perilaku Organisasi. Edisi 10. Yogyakarta: Andy.

Mangkunegara, Prabu, Anwar. 2013. Manajemen sumber daya manusia perusahaan. Bandung: PT Remaja Rosdakarya.

Mathis and Jackson. 2002. Manajemen Sumber Daya Manusia. Jakarta: Salemba Empat.

Manullang. 2001. Manajemen Personalia. Yogyakarta: Gajah Mada University Press.

Manuel G.Velasquez, 2005, Etika Bisnis, Konsep dan Kasus, Edisi 5, Andi, Yogyakarta.

Nugroho, A.B. 2015. Strategi Jitu Memilih Metode Statistik Penelitian dengan SPSS. Penerbit Andi, Yogyakarta.

Rivai, V. 2006. Manajemen Sumber Daya Manusia untuk Perusahaan dari Teori ke Praktik. PT Raja Grafindo Persada, Jakarta.

Santoso, G. 2004. Manajemen Keselamatan dan Kesehatan Kerja. Prestasi Pustaka, Jakarta.

Singarimbun, M dan Effendi S. 2005. Metode Penelitian Survai. LP3ES, Jakarta.

Suardi, R. 2005. Sistem Manajemen Keselamatan dan Kesehatan Kerja. Penerbit PPM, Jakarta. 